\title{
Refugia Roundtable
}

\section{Imagining Refugia \\ Thinking Outside the Current Refugee Regime}

\author{
Nicholas Van Hear
}

\begin{abstract}
Against the background of the refugee and migration crises of the last three years, this contribution takes as a starting point recent proposals that explore alternatives to the current international migration and refugee architecture. One strand of proposals explores the idea of new nations, cities, or polities for refugees and migrants-often dismissed as fantasies by many commentators. After briefly reviewing these proposals, the article explores the possibility not of a new "refugee nation," but rather a new kind of transnational polity-Refugia_created and governed by refugees and migrants themselves, and which links refugee and migrant communities globally. Such a transnational polity is imperfectly prefigured in many of the transnational practices that refugees and migrants deploy and the environments in which they find themselves today. Consolidating them pragmatically into a common polity-Refugiamight prove to be a way out of the current impasse.
\end{abstract}

KEYWORDS: alter-governance, durable solutions, migrants, mobile commons, pragmatic utopianism, refugees, Refugia

The refugee and migration summits in the US in September 2016 rounded off no fewer than seven major international meetings in that year that set out to solve the refugee and migrant "crisis" that escalated from around 2015 (Migration Policy Institute [MPI] 2016; UN 2016). Indeed, 2016 was dubbed "The Year of Summits." While the aims and sentiments articulated at these meetings were worthy and worthwhile, there was little confidence outside refugee and migration regime circles that such summitry held much promise of real progress: the outcomes were pledges on funding and resettlement that looked unlikely to be honored, and the prospect of "Global Compacts" on refugees and to promote safe, orderly, and regular migration, due to be agreed by the end of 2018 (Crisp 2017; Siegfried 2017).

Nor is there much confidence that the three conventional "durable solutions" (local integration, resettlement, and return) can address the challenge on the scale needed: more than 65 million people are currently displaced inside and outside their countries (UNHCR 2016a). There are serious limits and constraints-economic, ecological, institutional, cultural, and politicalin realizing any of the "durable solutions." They provide an answer for just a small proportion of the world's displaced (IRIN 2015), the vast majority of whom exist for years or even decades in "protracted displacement" - a state of limbo in camps or self-settled in cities enduring pre- 
carious and constrained conditions, without legitimate means of making a living or leading a decent life.

Moreover, those institutions and sections of civil society that support tolerant attitudes towards refugees and migrants are under strong attack from populist forces in many countries. Indeed, the way ahead looks increasingly bleak, as what Hungarian Prime Minister Viktor Orban has chillingly called "illiberal democracy," with its razor wire fences and inward-looking nativism, looks to take hold, not just in "post-socialist" and "emerging" countries (Poland, Hungary, Turkey, Egypt, India, and others), but in "liberal" ones as well: witness Trump, Brexit, and the far right's strong showing in many parts of Europe in 2016-18. So perhaps we are moving to a situation in which neoliberalism in economics sits alongside neo-illiberalism in politics and culture.

Against this grim background, this contribution takes as a starting point various recent proposals-some of them in the realms of fantasy-to depart from the usual three "durable solutions" and think about alternatives to the existing international architecture that seeks to address mass displacement and mobility more generally.

One set of proposals explores the idea of new nations, cities, or polities for refugees, often proposed by billionaires-turned-philanthropists. Three "island solutions" are highlighted briefly here:

- San Francisco real estate magnate Jason Buzi’s "Refugee Nation," which involves buying or leasing an island (in the Philippines or Indonesia, he suggests) or paying a sparsely populated country to house refugees and thereby create a new nation, the character of which he sets out in some detail (Taylor 2015b). ${ }^{1}$

- Egyptian telecoms billionaire Naguib Sawaris' proposal to spend $\$ 100$ million to buy an island in Greece or Italy to house refugees (Taylor 2015a).

- Dutch architect Theo Deutinger's proposal to create an artificial island between Tunisia and Italy which would accommodate a new city-state housing refugees. Calling it "Europe in Africa" (EIA), his idea is to reclaim land from the sea and lease it from Tunisia and Italy, thereby creating a new country, with its own passport, constitution, economy, and social system - under the protection of the European Union (Cohen and Van Hear 2017; Europe in Africa 2016; Taylor 2016).

We may note in passing that Thomas More's Utopia was an island-connected to the mainland in some versions by a small isthmus (More [1616] 2016).

These suggestions-particularly the idea of "refugee islands"- have been dismissed as fantasies by many commentators. Indeed, mixing migration, islands, and enclaves has a bad press: Nauru, Manus Island, Christmas Island, and Guantanamo Bay come to mind, bringing associations of containment and incarceration. Moreover, most of the proposals-including the kindred ideas of charter cities, free havens, and special zones-envisage deregulated places that are the dream spaces of neoliberal zealots.

But despite these caveats, perhaps some version of these ideas may be worth looking at. In this article, I explore the possibility not of islands or territorially bound new nations, but of a transnational polity-Refugia-created and governed by refugees themselves and which links refugee communities globally. The term Refugia was coined by Robin Cohen in a discussion of the limits and possibilities of Jason Buzi's Refugee Nation as a putative resolution to the migrant and refugee crisis (Cohen 2015). This article takes the idea in a different, transnational direction, as will become clear in what follows (see Van Hear 2016 for a preliminary version, and Cohen and Van Hear 2017 for a further exposition). To introduce the idea, we will move from a 
past utopia (Thomas More's Utopia, whose five hundredth anniversary was marked in 2016) to indulge in some future fantasizing, and fast forward some 12 years to the year 2030.

\section{Refugia 2030}

It is 2030 .

Trends that emerged in the late 2010s towards the polarization of liberal cosmopolitans and illiberal parochials have hardened. This is reflected spatially by the division of the world into metropolitan, liberal megacities with progressive administrations, often in conflict with the authoritarian national governments of the countries in which they sit. The latter's power is drawn from conservative supporters in smaller towns and the countryside.

Even more seriously, identity conflicts fueled by ethnic, nationalist, and religious loyalties continue to convulse many parts of the world, particularly a swath of territory from Western China to Western Africa, where religious and ethno-nationalist insurgents are locked in intermittent low-level conflict that erupts into full-scale war from time to time. Big and "emergent" powers-China, India, Russia, Europe, the USA, Brazil, Indonesia, Iran, Saudi Arabia, and others-continue to be dragged into many-sided proxy wars. It is a global condition that analysts have come to term permaconflict, and millions of refugees are on the move as a result.

More positively, a transnational polity called Refugia is consolidating itself after a shaky start in 2020 following the failure of the Global Compacts. Beginning as a global sociopolitical movement, it is not a new nation-state, but rather a transnational or cross-national entity. Confederal in character, the best analogy is with a loosely connected archipelago that brings together refugee communities in territories neighboring societies in conflict, as well as in more distant countries of settlement.

Refugia is in part the outcome of a grand bargain-between richer states and "emergent" countries, countries neighboring conflicts, and, crucially, refugees themselves. The constituent territories of Refugia are in effect licensed-or at least tacitly tolerated-by the nation-states within whose territories they lie. The collective name for such nation-states in which Refugia sites are located we will call Somewhereland. ${ }^{2}$ Some South European, West African, West Asian, and South American states took an early lead in accommodating a Refugium (a component of the transnational collectivity Refugia), and the municipal administrations of some liberal-run megacities do likewise-sometimes against the wishes of the authoritarian nation-states in which they lie.

\section{Governance}

The constituent components of the Refugia polity are self-governing and eventually selfsupporting. Refugia as a whole is governed by a transnational virtual assembly, elected by Refugians from all the constituent components of the polity. This represents Refugia globally, but there are also constituent assemblies in each Refugia location to contribute to this global representation, as well as to represent the interests of Refugians to the Somewhereland host societyand to channel the concerns of the host society to Refugians.

Refugians hold dual belongings: they can move among different parts of Refugia, and, where negotiated, between Somewhereland sovereign nations. ${ }^{3}$ They could also be citizens or longterm residents of the Somewhereland states that license their territories, in which case they are subject to the laws of both Refugia and the Somewhereland host state. Some Refugians live in discrete territories or spaces; others live side by side with Somewherelanders, especially in large, 
metropolitan cities. ${ }^{4}$ Moreover, the citizens of Somewhereland "host" societies can become Refugians if they wish-and indeed many do as they seek alternative forms of living to those that obtain in the authoritarian regimes that hold sway in most of the world. So as well as those displaced by conflict, Refugia attracts the "left-outs" of neo-illiberalism, just as "illiberal democracies" appealed to and incorporated the "left-behinds" of neoliberal globalization in the 2010s. The upshot is that refugees are no longer primarily the responsibility of the Somewhereland nation-state that "hosts" them, but of a more diffuse entity-Refugia.

\section{Economy}

Refugia's economy builds on the skills of Refugians in cultural and creative industries, education, and digital commerce and services, and some employment has been reluctantly negotiated in Special Economic Zones located between Refugia and Somewhereland. Also by mutual agreement, some Refugians can work in Somewhereland proper. Substantial portions of the stock of housing and commercial property are held in trust by Refugia to accommodate and provide work spaces for the "churn" of Refugians passing through different parts of Refugia over time. Refugians pay taxes or graduated contributions to the nation-states within which they live, but also to the wider Refugia polity. A portion of the latter revenue provides support for those who choose to stay in their regions of origin - in a similar manner to the way in which remittances are deployed now. It is a more systematic means (than remittances) of cross-subsidy among differently endowed parts of Refugia.

\section{Education}

There is a Refugia international baccalaureate taught digitally through distance learning and recognized across all Refugia locations, and increasingly in Somewhereland. Education is a key employer across the whole transnational polity.

\section{Overall Character}

Refugia is not based on ethnicity, nationality, or religion. Permaconflict has convinced many people of the fallacy of basing communities on such identifications. Moreover, people have of necessity been pressed into collective activity across such affiliations by their experience of forced movement. Differences are respected, but Refugians have been driven by their experiences (and aided by concerned citizens of the countries they have passed through) to create a new kind of polity that is democratic and self-sustaining - and not based on identity politics. It is a pragmatic arrangement that can perhaps be seen as a kind of secession by mutual agreement. For their part, authoritarian states see it as in their interest to shuffle off the displacement problem to be managed by the displaced themselves, while the displaced and those seeking an alternative to authoritarianism relish the prospect of a self-managed new society that they create themselves.

\section{Refugia Now}

If you think that all of this is utterly utopian, consider this-Refugia already exists in prefigured, albeit highly imperfect form, often in the transnational practices of refugees and migrants. Let me make the case for this assertion. 
In countries that have long hosted large numbers of refugees and will likely do so for the foreseeable future-Jordan, ${ }^{5}$ Turkey, Lebanon, Iran, Pakistan, Kenya, Ethiopia, and Uganda, among others-refugees have established tenuous communities against the odds of challenging conditions and poor prospects. These populations have links with more fortunate kin and friends in global cities further afield-not just in neighborhoods of New York, London, Paris, Berlin, Toronto, and Sydney, but of Istanbul, Cairo, Nairobi, Johannesburg, Mumbai, Delhi, Rio, Bangkok, and many others in the "emerging" and "post-socialist" world, where people of diverse ethnicities and backgrounds are thrown together.

Indeed, in some cases the diasporic populations in metropolises outside the homeland are as large as or larger than the population at home-for example, Toronto's Sri Lankan Tamil population is at least double that of Jaffna, the Tamils' cultural capital in Sri Lanka itself. One could say that the center of gravity of many of the world's ethno-national groups that have become "diasporized"-including the Tamils, Palestinians, Kurds, Nepalis, Somalis, Afghans, and Armenians, to give just a few examples-lies outside the country of origin. So these diasporic communities already inhabit the kind of transnational space that we envisage as Refugia.

Taken together, people in these dispersed locations constitute transnational communities through their diasporic connections. Indeed, transnationalism is already an enduring if not a durable solution to their displacement and dispersal: transnationalism is what displaced and dispersed people do to make a life worth living. The transformational step towards a transnational polity would be to move beyond ethnic identification to a global affinity of the displaced-and of course that is a big step. The global affinity of the displaced includes not just refugees, but also those who are or feel displaced by neoliberal capitalism and authoritarianism and want to make a different society.

As for governance, many diaspora groups have created transnational bodies that could serve as partial models of governance. In some cases, transnational elections have been held that sustain such transnational institutions. An imperfect example is the Transnational Government of Tamil Eelam (TGTE), whose transnational assembly was elected in 2010 by Tamils living in more than 15 countries outside Sri Lanka (Brun and Van Hear 2012). The technical means of holding such transnational elections are becoming more and more sophisticated. ${ }^{6}$

As for finance, reference has already been made to remittances by refugees to their troubled homelands and regions-in effect a form of global redistribution of wealth somehow akin to taxation. Much of this money travels through self-organized informal money transfer systems like hawala and hundi, or through peer-to-peer mobile phone mechanisms like Mpesa in East Africa, which partly bypass states and formal banking set-ups. As many have pointed out, the scale of this transnational redistribution is huge (World Bank 2016). ${ }^{7}$

Proto-Refugia also exists in the realm of culture, seen in the transnational mobility of art, music, dance, language, and sport. For example, a refugee team was recognized at the Rio Olympic games in 2016-a very modest step in the big picture perhaps, but a tacit recognition of a body of people outside nation-state affiliation (UNHCR 2016b).

Other examples of imperfect and partial Refugia can be found in prototypical form. Several ideas for special zones and/or refugee cities have been proposed, from different ideological positions.

What may be called a neoliberal strand proposes to adapt the Special Economic Zones that have been established to promote free trade and manufacturing so as to designate areas outside the regulations normally governing refugee settlement, where refugees would be able to work and to establish businesses. Instead of being dependent on aid, the argument runs, they would establish economies based on internal markets and external investment. In their exploration of global solutions to the "broken refugee system," Alexander Betts and Paul Collier (2017) alight 
on the example of the King Hussein bin Talal Development Zone, a Special Economic Zone in Jordan not far from the Zaatari refugee camp, arguing that it would make sense to bring together the under-utilized labor in the camp and the labor-short commercial and industrial plant in the Special Economic Zone for mutual benefit. They suggest that this and similar examples could be generalized to form a global solution for mass displacement, though critics have pointed to the dangers of ghettoization and exploitation of refugees (Crawley 2017). Other proposals of similar stripe suggest the establishment of economically liberal "refugee cities."

A second, more communitarian strand engaging with the notion of refugee cities emerges from municipal- and community-led initiatives to encourage "sanctuary cities" and to transform camps into "refugee cities." Refugia is prefigured in the notion of Cities of Refuge or Sanctuary. A notable example is the case of "Barcelona, Refuge City," whose progressive mayor has welcomed refugees (albeit in relatively small numbers), against the wishes of the Spanish state (Barcelona City Council 2016; Colau 2015). Sanctuary cities (and other local jurisdictions) in the US and elsewhere present other examples-currently under attack in the US by the Trump administration (Lippert and Rehaag 2012; MPI 2016).

"Refugee cities" in the sense of community-led initiatives in refugee camps and settlements can be seen as further prefigurations of Refugia (Agier 2002; Hanappe 2017). As the time in refugee camps has lengthened and more refugees have found places to live in or near cities, urban settlements have developed cumulatively. An example is Camp Domiz, a Syrian refugee camp in northern Iraq that has been recast as a "Refugee Republic," as its inhabitants have set up community centers, shops, and places of worship. ${ }^{9}$

There are also some promising developments at the local level, in Greece and Italy for example. Hotel Oniro ${ }^{10}$ is an abandoned hotel occupied by activists and refugees, part of the autonomous communities in Exarcheia, the anarchist quarter of Athens. The former hotel is now home to 200-250 refugees who manage it themselves with the help of activist citizens (Loubani 2016). Riace is a small depopulated place in southern Italy, where, at the invitation of the far-sighted mayor, about 450 migrants drawn from more than 20 countries in Africa and elsewhere beyond Europe have been housed in abandoned apartment blocks. They make up about a quarter of the village's total population and have breathed life into a declining community (BBC 2016). ${ }^{11}$

A number of enclaves and proto-statelets currently host refugees. Two examples are highlighted here.

The Bekaa valley. With its long tradition of accommodating refugees (notably Palestinians), Lebanon has received at least 1.2 million Syrian refugees in the years since the Syrian conflict erupted in 2011, adding about 25\% to the country's estimated population of 4.6 million. Most of the refugees are self-settled in various ways, and the Bekaa valley has turned into a temporary home for many of them. There is a substantial Lebanese diaspora scattered throughout the world, some of whom maintain homes in Lebanon as well as in the global north-in North America, Europe, Australia, and so on. They may visit these homes for a few months in the year. A wealthier portion of the diaspora (particularly those in Canada) have such homes in the Bekaa valley. There seem to be at least three modes of refugee accommodation in the Bekaa valley that incorporate these "second homes":

- Refugees who have a direct or indirect relation with the absentee diaspora home ownerseither as relatives or friends-live in these houses or on land attached to the houses for free or for a nominal rent.

- Refugees unrelated to the owners who rent or squat on land from such absentee owners.

- Refugees who rent from non-governmental organizations which have in turn rented the land from absentee owners. 
These are very insecure settlements, vulnerable to demolition, as they have been repeatedly by the Lebanese authorities (Limoges 2017), but they nevertheless point to a promising transnational means of addressing displacement, temporarily at least.

Rojava. The mainly Kurdish enclave in northern Syria (aka the Democratic Federation of North Syria) is based on principles of direct democracy, non-discrimination in terms of ethnicity (it includes both Kurds and Arabs), gender equality, freedom of religion, and so on. While by no means flawless, Rojava seems to be one of the healthier developments in that troubled region. Despite coming under attack by Turkey and others, the enclave has accommodated more than fifteen thousand refugees from fighting in Mosul in neighboring Iraq and tens of thousands of people displaced internally within Syria, while its male and female militias have liberated people from Isis control (Knapp et al. 2016).

Very occasionally, there are significant initiatives led by progressive governments of nationstates. A case in point is Ecuador's experiment with visa-free entry in 2008. Some migration researchers have called the period in 2008 in Ecuador "a natural experiment" in open borders, as the leftist administration opened up the country to immigration from a global solidarity position (Freier 2013). The president announced a policy of "universal citizenship," as part of an agenda "to dismantle the 20th century invention of passports and visas" (Acosta Arcarazo and Freier 2015). The upshot was that anyone could enter Ecuador visa-free for a period of 90 days - and many availed themselves of this opportunity (often with a view to moving on to the US). But increasing difficulty of moving on to the US meant that many stayed in Ecuador, and the policy was partly rescinded. Even so, it marks an interesting and rare experiment in statelevel openness to outsiders.

To these examples we may add sanctuary movements, private and community sponsorship of refugees in Canada and elsewhere, the MOAS (Migrant Offshore Aid Station) refugee rescue private initiative formerly in the Mediterranean, and many other similar civil society and private initiatives (Long 2015).

As significant as these diverse, migrant-citizen, municipal, and very occasionally state-level initiatives are cross-ethnic and cross-national affinities that have emerged among people on the move: "mobile commons" activities in which collective actions by migrants and refugees drawn from different nationalities and ethnicities have built solidarity and effected change (Papadopoulos and Tsianos 2013). Examples include collective action by sub-Saharan Africans thrown together in emergent communities crossing the Sahara or holed up in Libya. Likewise, in 2015, Syrians, Afghans, Iraqis, Eritreans, and others cooperated (along with supportive citizens) in actions on the East Mediterranean route through Turkey, Greece, and the Balkans, notably in surges to breach the borders of south-east Europe (in Turkey, Greece, Macedonia, Serbia, Hungary, Austria, and Germany). Sometimes gatherings of refugees and migrants at choke-points have formed ephemeral communities and settlements, such as the Jungle, near Calais (now demolished), Idomeni camp on the border between Greece and Macedonia, or Ventimiglia on the frontier of Italy and France. These actions forced temporary changes in the European migration and asylum order, however short-lived such shifts have proved to be. Perhaps more sustained were the social media networks providing commentary on smuggling routes, rates, nodes, and bottlenecks as online manifestations of the mobile commons.

This is not just a very recent phenomenon. A further example of the mobile (or immobile) commons from a decade before the current migration and refugee crisis was the Midan Mustafa Mahmoud sit-in protest in Cairo in 2005. Occupied by Sudanese refugees fed up with their treatment by the Egyptian state and the lack of help from the Office of the United Nations High Commissioner for Refugees (UNHCR), the Midan or square acted as a "waiting room" for the UNHCR office nearby that subsequently became a temporary home, community, and site of 
collective protest, bringing together Sudanese refugees with many different statuses. The site and community featured strong mutual aid and solidarity ("We, the Sudanese refugees" was one of their slogans), but the protest was brutally broken up by the Egyptian authorities with substantial loss of life (Danielson Lanier 2016; Forced Migration and Refugee Studies Program [FMRS] 2006).

Squalid and desperate though the Jungle, Idomeni, and their ilk may be; far from perfect though micro examples like Riace and Hotel Oniro, and existing enclaves like the Bekaa valley and Rojava are; often ephemeral and vulnerable to state repression as have been protests like the Midan Mustafa Mahmoud occupation; the positive side is that such mobile commons initiatives and activities feature community creation and reproduction through mutual aid sustained by refugees and migrants en route and concerned citizens working together-and they thereby constitute prefigurative forms of Refugia.

\section{Conclusion}

Camps and communities in countries neighboring conflicts, neighborhoods in global cities, transnational political practices and money transfers, emergent communities and activities in disparate locations en route, initiatives by citizens and community groups: all are fragments in disparate locations that taken separately do not seem to promise much. But in the aggregate, they could add up to Refugia, imperfectly prefigured. Consolidating them into a common polity might prove to be a way out of the current impasse. In this vision, Refugia as a transnational durable solution will come about incrementally and cumulatively by the collective activity of refugees and sympathetic citizens organizing in the interstices of the nation-state system and the international governance architecture. Refugia will be essentially self-organized and selfmanaged, requiring neither political nor cultural conformity, but simple agreement on principles and deeds of solidarity and mutual aid.

Some would argue that this proposal could lead to the international ghettoization of refugees, confined to reservations on poor-quality land that no-one else wants, without means of generating income to create decent communities and lead a decent life. We recognize the danger of such dystopian nightmares-one such indeed unfolded in 2017 on the borders between Myanmar and Bangladesh. The key difference in our vision is that Refugia would be more than the sum of its isolated parts, with the option of mobility among its constituent territories as their political and economic circumstances ebb and flow.

Critics will no doubt dub this vision utopian, a jibe that is readily accepted, though with a qualification. Refugia embodies a "pragmatic utopianism" which tries to square the apparently contradictory and at times antagonistic interests of Somewhereland states and Refugians.

Viva Refugia!

\section{ACKNOWLEDGMENTS}

The ideas in this article have been developed with my colleague Robin Cohen. I am very grateful for incisive critical comments received at presentations in Oxford, London, Bonn, Tbilisi, Barcelona, Maastricht, Accra, Berlin, Helsinki, Oslo, and Turin, as well as to many others who have considered the ideas in this piece. 
NICHOLAS VAN HEAR is at the Centre on Migration, Policy and Society (COMPAS), University of Oxford. He works on forced migration, conflict, development, diaspora, transnationalism, and related issues, with field experience in Africa, the Middle East, South Asia, and Europe. His books include New Diasporas: The Mass Exodus, Dispersal and Regrouping of Migrant Communities (Routledge, 1998), The Migration-Development Nexus (International Organization for Migration, 2003), and Catching Fire: Containing Forced Migration in a Volatile World (Rowman and Littlefield, 2006). His main contributions have been on force and choice in migration; migration and development; diaspora formation and engagement in conflict and post-conflict settings; migration and class; and the interplay between mobility and political mobilization.

\section{NOTES}

1. www.refugeenation.org/ (last accessed 19 October 2018).

2. The name Somewhereland is an ironic nod to David Goodhart (2017), who, in his analysis of the appeal of populism, sees the world as divided between "Anywheres" (liberal rootless cosmopolitans) and "Somewheres" (grounded provincial folk deeply committed to place in small towns and the countryside). We may note in passing that Utopia means "no place," and that William Morris's most famous utopian tract was titled News from Nowhere ([1890] 1973). Refugia is somewhere, however, adjacent to Somewhereland.

3. See Cohen and Van Hear (2017) for a discussion of the Sesame card, which carries digital identity, entitlements, means of participation in governance, and other aspects of Refugia membership.

4. Speculative fiction offers some useful insights and ideas. Refugia is in some ways a benevolent version of the parallel urban settings in China Mieville's dystopian novel The City and the City (2009). It also resonates with Mohsin Hamid's novel Exit West (2017), which we came across after formulating the basic idea of Refugia.

5. In the last 70 years, Jordan has dealt with no fewer than six mass influxes: in 1948, 1967, 1982, 1990 (all Palestinians), then 2003 (Iraqis), and from 2011 (Syrians, including Syrian Palestinians).

6. See www.archive.whatdesigncando.com/challenge/project/refu-rendum/ for voting and other techniques of online consultation. As for the face to face world, in June 2018, after this article was written, the first Global Summit of Refugees was held in Geneva-arguably a prototype of the kind of assembly that we envisage as part of the governance of Refugia: www.networkforrefugeevoices.org/ global-summit-of-refugees.html (last accessed 19 October 2018).

7. According to the World Bank, migrant remittances totaled US $\$ 441$ billion in 2016, more than three times the amount of aid, and the total has increased inexorably in recent years (World Bank Group 2016).

8. Refugee Cities: Expanding Options for Displaced People through Special Economic Zones. Concept paper, November 2016. refugeecities.org/refugeecities.files.wordpress.com/2016/11/refugee-citiesconcept-paper-november-2016.pdf.

9. See refugeerepublic.submarinechannel.com/.

10. Perhaps appropriately, "Oniro" derives from the Greek oneiros, meaning dream. The bigger City Plaza Hotel in Exarcheia is perhaps a better known case, housing more refugees and activists.

11. As this article went to press, the mayor of Riace was arrested for helping refugee and migrants, against the background of a series of anti-immigration measures announced by Matteo Salvini, Italy's far-right interior minister. See www.theguardian.com/world/2018/oct/02/pro-refugee-italian-may or-arrested-suspicion-aiding-illegal-migration-domenico-lucano-riace (last accessed 19 October 2018). 


\section{REFERENCES}

Acosta Arcarazo, D., and L.F. Freier. 2015. “Turning the Immigration Policy Paradox Upside Down? Populist Liberalism and Discursive Gaps in South America." International Migration Review 49: 659-696. doi:10.1111/imre.12146.

Agier, M. 2002. "Between War and the City: Towards an Urban Anthropology of Refugee Camps." Ethnography 3 (3): 317-341.

Barcelona City Council. 2016. Barcelona, Refuge City. ciutatrefugi.barcelona/en/inicio.

BBC. 2016. "Riace: The Italian Village Abandoned by Locals, Adopted by Migrants." BBC, 26 September. www.bbc.co.uk/news/in-pictures-37289713.

Betts, A., and P. Collier. 2017. Refuge: Transforming a Broken Refugee System. London: Allen Lane.

Brun, C., and N. Van Hear. 2012. "Between the Local and the Diasporic: The Shifting Centre of Gravity in War-Torn Sri Lanka’s Transnational Politics." Contemporary South Asia 20 (1): 61-75.

Cohen, R. 2015. "Refugia: The Limits and Possibilities of Buzi's Refugee Nation." https://nandosigona .wordpress.com/2015/07/30/refugia-the-limits-and-possibilities-of-buzis-refugee-nation/

Cohen, R., and N. Van Hear. 2017. "Visions of Refugia: Territorial and Transnational Solutions to Mass Displacement." Planning Theory and Practice 18 (3): 494-504.

Colau, A. 2015. "We, the Cities of Europe." Blog, 13 September. ajuntament.barcelona.cat/alcaldessa/en/ blog/we-cities-europe.

Crawley, H. 2017. "Migration: Refugee Economics." Nature 544: 26-27.

Crisp, J. 2017. "New York Declaration on Refugees: A One-Year Report Card." Refugees Deeply, 18 September. www.newsdeeply.com/refugees/community/2017/09/18/new-york-declaration-onrefugees-a-one-year-report-card.

Danielson Lanier, N. 2016. "Asylum at an Impasse: Refugee Protest and the Politics of Asylum Governance in Cairo." Unpublished doctoral thesis, Oxford.

Europe in Africa. 2016. "Europe in Africa." www.europeinafrica.com/.

Forced Migration and Refugee Studies Program (FMRS). 2006. A Tragedy of Failures and False Expectations: Report on the Events Surrounding the Three-Month Sit-in and Forced Removal of Sudanese Refugees in Cairo, September-December 2005. Cairo: The American University in Cairo.

Freier, Luisa Feline. 2013. "Open Doors (For Almost All): Visa Policies and Ethnic Selectivity in Ecuador.” Working Paper 188, University of California, San Diego, Center for Comparative Immigration Studies.

Goodhart, D. 2017. The Road to Somewhere: The Populist Revolt and the Future of Politics. London: Hurst.

Hanappe, C. 2017. "A Camp Redefined as Part of the City." Forced Migration Review 55: 33-34. www.fmreview.org/shelter/hanappe.html.

IRIN. 2015. "Durable Solutions for Refugees Prove Elusive." IRIN Analysis, Oxford, 10 July. http://www .irinnews.org/report/101735/durable-solutions-refugees-prove-elusive.

Knapp, M., A. Flach, and E. Ayboga. 2016. Revolution in Rojava: Democratic Autonomy and Women's Liberation in Syrian Kurdistan. London: Pluto Press.

Limoges, B. 2017. “Thousands of Syrians Face Eviction from Lebanon Camps.” Al Jazeera, 15 April. www.aljazeera.com/indepth/features/2017/04/thousands-syrians-face-eviction-lebanon-camps$170415042553730 . h t m l$ ?xif $=\& c=3729822841203851816 \& \mathrm{mkt}=\mathrm{en}$-us.

Lippert, R., and S. Rehaag, eds. 2012. Sanctuary Practices in International Perspectives: Migration, Citizenship and Social Movements. London: Routledge.

Long, K. 2015. “Private Money, Public Good?” Migrants and Citizens blog, 8 June. http://migrantsand citizens.org/blog/private-money-public-good/.

Loubani, Qusay. 2016. “Small, Illegal Refugee Paradise." openDemocracy, 13 October. www.opendemoc racy.net/5050/qusay-loubani/small-illegal-refugee-paradise.

Mieville, C. 2009. The City and the City. London: Macmillan.

Migration Policy Institute (MPI). 2016. "Focusing on Protection: Previewing Upcoming High-Level Fora on Migration." MPI, 27 January. www.migrationpolicy.org/events/focusing-protectionpreviewing-upcoming-high-level-fora-migration. 
More, Thomas. [1616] 2016. Utopia. Cambridge: Cambridge University Press.

Morris, William. [1890] 1973. News from Nowhere. Kelmscott Press/London: Lawrence and Wishart.

Papadopoulos, D., and V. Tsianos. 2013. "After Citizenship: Autonomy of Migration, Organisational Ontology and Mobile Commons." Citizenship Studies 17 (2): 178-196.

Siegfried, K. 2017. "New Refugee Framework 'Dead in the Water' without More International Support." IRIN News, 10 July. www.irinnews.org/analysis/2017/07/10/new-refugee-framework-dead-waterwithout-more-international-support.

Taylor, A. 2015a. "An Egyptian Billionaire Wants to Buy an Island to House Refugees." Washington Post, 4 September. www.washingtonpost.com/news/worldviews/wp/2015/09/04/an-egyptian-billionairewants-to-buy-an-island-to-house-refugees/?utm_term=.bda115f7b227.

Taylor, A. 2015b. "Refugee Nation: A US Property Mogul's Simple Solution to the World's Migration Crisis-Create a New Country for Refugees to Live in." The Independent, 26 July. https://www .independent.co.uk/news/world/americas/refugee-nation-a-us-property-moguls-simple-solutionto-the-worlds-migration-crisis-create-a-new-10417235.html.

Taylor, A. 2016. "A Dutch Architect's Plan to Put Europe's Refugees on a Man-Made Island Near Tunisia." Washington Post, 1 June. www.washingtonpost.com/news/worldviews/wp/2016/06/01/ a-dutch-architects-plan-to-put-europes-refugees-on-a-man-made-island-near-tunisia/?utm_ term $=.4 \mathrm{e} 9 \mathrm{c} 343 \mathrm{a} 9791$.

UN. 2016. UN Summit for Refugees and Migrants. refugeesmigrants.un.org/summit.

UNHCR. 2016a. "Global Forced Displacement Hits Record High.” UNHCR, 26 June. www.unhcr.org/ news/latest/2016/6/5763b65a4/global-forced-displacement-hitsrecord-high.html.

UNHCR. 2016b. “These 10 Refugees Will Compete at the 2016 Olympics in Rio." UNHCR, 3 June. www.unhcr.org/news/latest/2016/6/575154624/10-refugees-compete-2016-olympics-rio.html.

Van Hear, N. 2016. "Imagining Refugia." Blog. www.compas.ox.ac.uk/2016/imagining-refugia/.

World Bank Group. 2016. Migration and Remittances Factbook 2016. 3rd ed. Washington, DC: World Bank. 


\title{
Refugia \\ A Place Where Refugees Survive, But Do Not Thrive
}

\author{
Veronique Barbelet and Christina Bennett
}

- ABSTRACT: Rethinking the traditional "care and maintenance" models and camp-based support to refugees is necessary. Evidence has shown that the traditional system and practice for assisting and protecting refugees are not addressing the needs of the 22.5 million people worldwide driven from their homes and residing outside of their own countries-often for decades. The type of foresight analysis put forward in "Imagining Refugia" can be helpful in identifying the inconsistencies and challenges of current systems. But such foresight analysis is only useful if it follows an evidence-based diagnosis of the problem. Refugia imagines a solution where refugees survive but do not thrive, offering a technical fix that ignores wider rights, economic opportunity, freedom of movement, and choice.

KEYWORDS: Cameroon, Jordan, livelihoods, Malaysia, refugee aspirations, refugee rights, Turkey

There is little doubt that the system and practice for assisting and protecting refugees requires a rethink. Traditional "care and maintenance" models and camp-based support are neither relevant nor adequate to address the 22.5 million people worldwide ${ }^{1}$ driven from their homes and residing outside of their own countries-often for decades, if not for generations. In this regard, the type of foresight analysis put forward in "Imagining Refugia" is often helpful: imagining future scenarios brings into sharp relief the inconsistencies, challenges, and hypocrisies of current systems and structures. It demonstrates how closely current systems are the product of power and interests of a specific time and place. In doing so, it allows one to identify the most important drivers of change. But such foresight analysis is only useful if it follows an accurate and evidence-based diagnosis of the problem. And here, "Imagining Refugia" may be missing the mark.

As part of its premise, Refugia assumes in-built solidarity that moves "beyond ethnic identification to a global affinity of the displaced." It characterizes refugees as a monolith that enjoys a common identity and shares common aspirations. While there are numerous examples of refugee-refugee support and solidarity (Hagen-Zanker and Mallett 2016; Humanitarian Practice Network (HPN) 2016; Omata 2013), the idea of refugee communities remains contentious in the refugee literature. Indeed, the literature has shown that refugees are often fragmented along ethnic, linguistic, and religious lines-even if (and particularly when) originating from the same country (Holt 1981; Moro 2004).

In our recent research in Malaysia, we found examples of solidarity and support as well as distrust among the Rohingya refugees. Refugees expressed concerns regarding trust, exploitation, and human trafficking when interacting with fellow Rohingya people, in part because many smugglers identified in refugees' stories were also Rohingya themselves. The mistrust 
also existed among refugee leaders who competed with each other and accused other leaders of being corrupt, informants for Malaysian authorities, or racketeers, exploiting the Rohingya community to make money (Wake 2016; Wake and Cheung 2016). In Cameroon, we found palpable tensions between the newly arrived Central African refugees, who were receiving the bulk of the aid money and attention, and those who had been there for more than five years, and who felt abandoned by aid organizations and weary of the negative impact of new refugees on their relationship with host communities (Barbelet 2017a, 2017b).

"Imagining Refugia" also fails to confront the political economy of most refugee situations and their corollary challenges of economic inequality and power imbalances. As a parastatal construct, Refugia both depends on and circumvents the state. Refugians are subject to the sovereign demands of their territorial hosts-in the form of laws, land use, and taxation, but without the benefit of sovereign responsibility, including rights, services, and protection. As a loose association of self-governed islands of refugee communities, Refugia also depends on its inhabitants having a level of bargaining power with willing and friendly host states without considering how improbable this is without major structural and behavioral changes in the current international aid system.

The problems inherent in such a state substitution model are well known-UNHCR has long faced similar challenges - and any of the potential perks outlined by Refugia (refugee bargaining power, strength in solidarity) fall well short of refugee expectations and aspirations in real life. The author of Refugia fails to consider the evidence that most refugees aspire to return home when peace comes, or become citizens of another state, with all the rights, opportunities and privileges, and sense of belonging that entails. Refugia also neglects the fact that none of these initiatives will have tangible impacts unless other dimensions of rights (legal protection, freedom of movement, etc.) are addressed. In the current international system, it is difficult to see who else could grant such rights if not nation-states. The fact that citizens of Somewhereland can become Refugians is perhaps one of the more progressive aspects of the proposal.

Refugia's economic proposition, which envisions willing territorial entities (states, municipalities) allowing refugees to live and work in camps and in Special Economic Zones, also fails to support the lives of refugees in a way that is acceptable, permanent, and fulfilling. Although linked to the current discourse on work permits and jobs, Refugia similarly imagines a timebound and carefully controlled right to work with no prospects for permanence and opportunity for growth. Refugees we interviewed for our research in Turkey and Jordan were disappointed and frustrated by current proposals to allocate temporary permits to work in pre-designated job sectors and for pre-selected employers, as such proposals did little to improve the precarious situation they found themselves in (Barbelet and Wake 2017a). Instead, refugees worried that formal work permits would lead to more-not less-exploitation by employers than their current working conditions in the informal sector (Bellamy et al. 2017). Where Special Economic Zones were put in place in Jordan, they failed to bring about real economic opportunities for refugees or allow them to fulfill their non-work aspirations such as maintaining family unity, ensuring a better future for their children, and safety. In Cameroon and Uganda, a focus on jobs failed to consider that economic security for refugees requires a range of interventions addressing the wider issues of chronic underdevelopment (Barbelet and Wake, 2017b).

Where "Imagining Refugia" is useful, however, is in highlighting the many initiatives that already exist. Solidarity movements that bring together concerned citizens with refugees from different nationalities, such as the Worldwide Tribe supporting refugees arriving in Europe, are already a great source of hope and possibility for some refugees. And in Malaysia for instance, where refugees live and work in a highly restrictive policy environment, our research found evidence of individual compassion and tolerance: an employer who puts his name down for 
a refugee to buy a motorcycle; a police officer who takes pity on a Rohingya refugee with his children going to work illegally; and so on. But such movements and random acts of kindness have their limitations, as we have seen for example in Europe, where volunteer movements have struggled to bring their energy and voices together to bring about real change in refugee lives (Borton and Collinson, 2018).

As a device for amplifying the pathologies of the current refugee architecture and identifying some potential levers of change, "Imagining Refugia" provides ample food for thought on the required shifts to promote better lives for refugees.

But Refugia imagines a solution where refugees survive but do not thrive, offering a technical fix that ignores wider rights, economic opportunity, freedom of movement, and choice. While this may be better than the status quo, it does not address the economic, legal, and social precarity that dominate refugees' sense of identity, livelihoods, and outlook, which are essential to achieve improved lives for refugees.

VERONIQUE BARBELET is a political scientist by training with a particular interest in humanitarian policy, humanitarian negotiations with armed non-state actors, conflict and security, protection, gender-based violence, and livelihoods. Previously she worked at the World Food Programme as a protection policy officer with a focus on displacement settings. In the last two years, she has conducted research on the livelihoods of refugees in Cameroon, Jordan, and Turkey and co-authored the project's final report bringing together analysis from the case studies and their policy implications.

CHRISTINA BENNETT is Head of Programme for the Humanitarian Policy Group (HPG), with close to 20 years of experience in humanitarian policy and programming. While at HPG, Christina has focused on analyzing the changing humanitarian landscape and its implications for humanitarian principles, architecture, and partnerships. Prior to joining HPG, Christina was the Chief of Policy Analysis and Innovation at the United Nations Office for the Coordination of Humanitarian Affairs (OCHA), where she led OCHA's analytical efforts on a range of humanitarian issues, including aid effectiveness, risk and resilience, and civilian protection.

\section{NOTE}

1. United National High Commissioner for Refugees (UNHCR) estimates that in 201622.5 million people had to flee their country to seek refuge. This includes 17.2 million refugees under UNHCR mandate and 5.3 million Palestinian refugees registered by United Nations Relief and Works Agency for Palestine Refugees in the Near East (UNWRA).

\section{REFERENCES}

Barbelet, V. 2017a. Livelihood Strategies of Central African Refugees in Cameroon: "No One Should Have to Be a Refugee." HPG Working Paper. London: ODI.

Barbelet, V. 2017b. Supporting Central African Refugees in Cameroon: Policy and Practice in Response to Protracted Displacement. HPG Working Paper. London: ODI. 
Barbelet, V., and C. Wake. 2017a. The Lives and Livelihoods of Syrian Refugees in Turkey and Jordan. HPG Summary Report. London: ODI.

Barbelet, V., and C. Wake. 2017b. Livelihoods in Displacement: From Refugee Perspectives to Aid Agency Responses. HPG Working Paper. London: ODI.

Bellamy, K., S. Haysom, C. Wake, and V. Barbelet. 2017. The Lives and Livelihoods of Syrian Refugees: A Study of Refugee Perspectives and Their Institutional Environment in Turkey and Jordan. HPG Commissioned Report. London: ODI.

Borton, J., and S. Collinson. 2018. Responses to Mixed Migration in Europe: Implications for the Humanitarian Sector. HPN Network Paper. London: ODI.

Hagen-Zanker, J., and R. Mallett. 2016. Journeys to Europe: The Role of Policy in Migrant Decision-Making. London: ODI.

Holt, J. 1981. “Camps as Communities.” Disasters 5 (3): 176-179. http://doi.org/10.1111/j.1467-7717 .1981.tb00985.x.

Humanitarian Practice Network (HPG). 2016. "Refugees and Vulnerable Migrants in Europe." Humanitarian Exchange Magazine 67. https://odihpn.org/magazine/refugees-vulnerable-migrants-europe/.

Moro, L.N. 2004. "Interethnic Relations in Exile: The Politics of Ethnicity among Sudanese Refugees in Uganda and Egypt." Journal of Refugee Studies 17 (4): 420-436. http://doi.org/10.1093/jrs/17.4.420.

Omata, N. 2013. "Community Resilience or Shared Destitution? Refugees' Internal Assistance in a Deteriorating Economic Environment.” Community Development Journal 48 (2): 264-279. http://doi.org/ $10.1093 / \mathrm{cdj} / \mathrm{bss} 057$.

Wake, C. 2016. "Turning a Blind Eye": The Policy Response to Rohingya Refugees in Malaysia. HPG Working Paper. London: ODI.

Wake, C., and T. Cheung. 2016. Livelihood Strategies of Rohingya Refugees in Malaysia: "We Want to Live in Dignity." HPG Working Paper. London: ODI. 


\title{
Beware of Social Engineering \\ A Response to "Refugia" by Nicholas Van Hear
}

\author{
Helma Lutz
}

ABSTRACT: This response to "Refugia" discusses four moments of dissent concerned with the ideas of social engineering in Nicholas Van Hear's thought experiment. I point out: (a) the problems of building a humane society by people with traumatized biographies; (b) the broad variation of refugees' experiences and motives to flee their conflict-ridden country, which may hamper the building of a new humane society; (c) the necessity to make compulsory the compliance with anti-discrimination laws, human, women's, and children's rights; and (d) the danger that the economic foundation of Refugia may be based on a free trade zone agreement that encourages the exploitation of refugees by international companies-as is already the case in many larger refugee camps across the globe.

KEYWORDS: compliance, dependence, refugee nation state, social engineering, trauma

Arise ye workers from your slumbers

Arise ye prisoners of want

For reason in revolt now thunders

And at last ends the age of cant.

Away with all your superstitions

Servile masses arise, arise

We'll change henceforth the old tradition

And spurn the dust to win the prize.

-Eugène Pottier (Paris, 1871)

The number of people fleeing from war and violence, deprived of their homes, belongings, and beloved, is rising to new peaks by the day, and laterally reversed, the number of states and people denying them refuge, shelter, and "the right to have rights" (Arendt) seems to increase equally. Nicholas Van Hear's "Refugia," therefore, is the urgently needed thought experiment about the way out of this impasse. While following him on the general idea, I have my doubts about the conditions on which his "2030" utopia of a collective's sustainable livelihood is built.

A. From a gender and intersectionality perspective, the consideration of differences between refugees seems to me an important issue for the conceptual design of a utopian society. The invocation of people into the category of refugee or Refugian does not do away with their (gendered, ethnic, national, religious, sexual) preferences and differences. While (in 2030) millions of refugees flee violent "identity conflicts fed by ethnic, nationalist, and religious loyalties," Van Hear imagines that the settlers of Refugia who have been "pressed into col- 
lective activity across those affiliations" are committed to respect differences. The latter, however, is not an automatic outcome of violent war zone experiences; the result may well be the opposite, a collective rancor against the oppressing ethnicity and rage prone to erratic eruption. Few refugees have the privilege of taking a plane into Refugia; the great majority have experienced hunger, thirst, violence, exploitation, torture, and rape en route, sometimes for years. Traumatic experiences do not disappear automatically when refugees have reached a "safe haven." Building a just and humane society in Refugia requires a lot of (political and communicative) skills (acquired by training, coaching, supervision) and implies a willingness to overcome the desire for revenge.

B. This resonates with my second objection. Van Hear's Refugia somehow reveals a form of the (Marxist) dream that a new society and a "new humanity" can be built by the (sub) proletarians or the subalterns, by people who share experiences of oppression and exclusion (see the first verse of the "International" above). History has proved this approach wrong, for many reasons. In the case of Refugia it is, therefore, important to be aware of the multitude of causes and aims that make refugees leave their countries behind. Among those fleeing are not only victims of violence, but also perpetrators. In her most recent novel (The Ministry of Utmost Happiness), Arundhati Roy describes a vivid example of how a torturer and his family fake a story of persecution convincingly because of their insider knowledge, on the basis of which refuge is granted. What I want to underline is that-as was the case in the workers' movements of the twentieth century-refugees' motives and views of the future may be utterly divergent.

C. The idea that Refugia will be based on principles of equal opportunity, solidarity, and reciprocal support is preconditionally dependent not only on sufficient (economic and political) resources but also on a general agreement about the meaning of justice/a "just" society. This consensus is not a given but needs to be established through long-term learning processes in which, for example, compliance with anti-discrimination laws, human, women's, and children's rights is established.

D. And lastly, what kind of economic system will Refugia adopt? Will it be a free trade zone in which large corporations find cheap laborers? Or to put it another way: how can the government of Refugia guarantee that large IT and similar companies do not exploit refugees as service workers-something that is already the case in many of the large refugee camps in the Middle East? In a place where alternatives are absent, people do not have much choice about whom to work for and what kind of work is performed. How can the influence of international companies be reduced or kept away? How can a banana republic be avoided?

The challenges to building Refugia as a just and humane society are manifold. I agree with Van Hear that it is, nevertheless, worthwhile thinking about it. In every thought experiment, however, there are blind spots. My key argument here is that the building of a "new society" that embodies what in many societies of the world is absent-for example, justice, freedom, equality, and human and women's rights, the abolition of discrimination on the basis of gender, class, race/ethnicity, sexuality, religion, age, and nationality-requires skills that cannot be assumed offhand. Therefore, Theo Deutinger's creation of "Europe in Africa" on an artificial island between Tunisia and Italy will most probably become a Mecca for artists and architects from all over the world, but it is very unlikely that it will become a functioning "refugee nation," as the multitude of examples of failed experiments of social engineering from the twentieth century have shown us. 
HELMA LUTZ is Professor in Sociology and the chair of women's and gender studies in social sciences at Goethe University Frankfurt, Germany. Since 2015 she has been executive director of the Cornelia Goethe Center of Women's and Gender Studies, and since 2017 the director of the Graduate Center Gender for Early Career Researchers. She also serves as president of the Research Committee RC05 of the International Sociological Association (2018-2022). Lutz has a long-standing record of research in the field of gender, migration, care, ethnic relations, racism, and intersectionality, and has carried out research projects in various locations in Europe. Her publications to date include 19 books (six monographs and 13 co-editorships) and more than 100 articles in journals and books in six languages. 


\title{
Refugia \\ Pragmatic Utopianism
}

\author{
Nicholas Van Hear
}

- ABSTRACT: In this response to colleagues' perceptive comments that engage critically with the idea of Refugia I will focus on two related sets of issues that feature in the critiques, and which have come up persistently when the Refugia idea has been presented in other forums: the social and economic viability of Refugia, and the linked issues of rights and power.

KEYWORDS: alter-governance, durable solutions, migrants, mobile commons, pragmatic utopianism, refugees, Refugia

The perceptive comments by Veronique Barbelet, Christina Bennett and Helma Lutz are very welcome for their critical engagement with the idea of Refugia. There is not space here to do full justice to them: my colleague Robin Cohen and I try to address these and other critical comments more fully in a forthcoming book. Here I will focus on two related sets of issues that feature in the critiques, and which have come up persistently when the Refugia idea has been presented in other forums: the social and economic viability of Refugia, and the linked issues of rights and power.

\section{Viability}

The commentators are rightly skeptical that displacement alone would be sufficient to bind together the populace that makes up the Refugia transnational polity. Moreover, the idea appears to assume a kind of unity that is lacking given divisions of class, ethnicity, religion, gender, generation, and other social cleavages among the displaced, not to mention deep-seated enmities generated in the course of conflict and displacement.

Refugia would indeed have to address such challenges so as to create a good society in which diverse Refugians are assured of a decent life, as well as forging common identity and purpose. We see Refugia emerging organically and cumulatively from a sociopolitical movement that brings together the disparate solidarities and transnational practices that we can see in evidence today. Those practices and solidarities already embody commitment to various kinds of social justice, imperfect and incomplete though that may be. Refugia will only emerge if there is a political and not least emotional investment on the part of displaced people and Somewhereland supporters and dissidents who relish the idea of creating a new society that draws strength from its transnational character.

Our utopianism is pragmatic enough to recognize that there would have to be compromises, not least on the economic front, and especially in the early stages. Hence some Refugians may indeed perforce have to accept exploitative conditions in Somewhereland states (as is the 
case now). Over time though, distance work involving services and products of a digital kind combined with an internally generated economy would diminish such dependence with the emergence of a self-sustaining economy. The multi-sitedness of Refugia will be an asset in the creation of a transnational good society over time, not least in making possible a measure of redistribution of resources across its constituent sites.

\section{Rights and Power}

The commentators also see substantial challenges with upholding Refugians' rights, not least in the context of potentially hostile Somewhereland neighbors. But by emerging alongside the existing nation-state order, perhaps Refugia opens up a way to finesse the rights debate. After all, the record of nation-states and international organizations in upholding rights is patchy, to say the least, and especially in the current climate. Arguably, reliance on such authorities to uphold rights is misplaced. Better perhaps to step away from the current set-up and accumulate the power and capacity to manage one's own affairs in a new kind of polity that seeks accommodation with the nation-state system at arm's length-however uneasy such an accommodation may be. Refugia would thus seek to assure a just society and a decent life in the interstices of the nation-state system. Moreover, it should be remembered that in our vision being a Refugian would not be compulsory: those who do not see their future in Refugia could continue to take their chances with the asylum system of the existing nation-state order (and its limited upholding of rights).

In our vision, refugees, other migrants, and Somewhereland dissidents will incrementally engineer in Refugia a transnational good society in which people and communities can indeed thrive. This may not be utopia, but pragmatic utopian thinking offers an opportunity at least to dream of such a society and its challenges.

\section{NOTE}

The article in this issue to which the discussants responded was written more than a year ago, and our thinking has moved on since. Readers who wish to get a sense of our latest thinking may consult www.compas.ox.ac.uk/project/the-refugia-project/. 